\title{
SEASONAL CHANGES IN A POPULATION OF DESERT HARVESTMEN, TRACHYRHINUS MARMORATUS (ARACHNIDA: OPILIONES), FROM WESTERN TEXAS
}

\author{
By William P. MacKay ${ }^{1}$, Che'Ree Grimsley ${ }^{1}$, \\ AND JAMES C. COKENDOLPHER ${ }^{2}$
}

\section{INTRODUCTION}

Other than a few of the common insects, we know little about arthropod populations in North American Deserts (Crawford, 1981). This seems to be especially true of arachnids. A few papers have appeared on desert spiders, solpugids (Muma, 1980a, 1980b and included references), desert scorpions (Polis, 1990) and harvestmen of southwestern New Mexico (Cokendolpher et al., 1993).

Harvestmen, like other desert organisms, must synchronize their seasonal activity patterns with yearly changes in environmental conditions. In this paper, we provide information on the phenology of a population of the harvestman Trachyrhinus marmoratus, which is locally abundant on rocky slopes in the northern Chihuahuan Desert.

\section{MATERIALS AND METHODS}

\section{Study Area}

Our study area, the Indio Mountain Research Station, is located in the Chihuahuan Desert, $25 \mathrm{~km}$ south of Van Horn, Hudspeth Co., TX $\left(30^{\circ} 45^{\prime} \mathrm{N}, 105^{\circ} 0^{\prime} \mathrm{W}\right)$. It consists of an area uninhabited and undeveloped by humans, including sloping bajadas and rugged slopes with rocky outcrops. Natural vegetation types range from tobosa-black grama grassland to creosotebush-lechugilla shrubland. Rainfall is normally less than $25 \mathrm{~cm} / \mathrm{yr}$, and occurs primarily in late summer and fall. Air temperatures range from below $0^{\circ} \mathrm{C}$ in the winter to over $40^{\circ} \mathrm{C}$ in the summer. The specific area we used consists of a volcanic boulder and rock covered ridge at an elevation of $1235 \mathrm{~m}$. The ridge is surrounded on both sides (north and

\footnotetext{
${ }^{1}$ Laboratory for Environmental Biology and Department of Biological Sciences, The University of Texas, El Paso, TX 79968

2007 29th Street, Lubbock, TX 79411

Manuscript received 29 September 1992.
} 
south, ca. $40 \mathrm{~m}$ lower in elevation) by creosotebush scrub flatlands on a sand/ash gravel substrate.

\section{Population Sampling}

We used pitfall traps to sample the harvestman population. Pitfalls consisted of $350 \mathrm{ml}$ (12 oz Solo brand) plastic cups placed within $470 \mathrm{ml}$ (16 oz Solo) plastic cups. A 1:19 mixture of ethylene glycol:ethanol (absolute) was used in the cups as a preservative. The volume used was ca. $20 \mathrm{ml}$ in the cooler months, $100 \mathrm{ml}$ in the warmer months. The solution would occasionally dry to ethylene glycol.

Ten traps were placed ten meters apart along each of six one hundred meter transects. Two transects were placed on the north side of the ridge, two along the top of the ridge and two on the south side of the ridge. Uncovered traps were active for $24 \mathrm{hr}$ periods during 14 days in 1991 (6 Jan., 2 \& 22 April, 26 May, 9 \& 23 June, $7 \& 20$ July, $7 \& 25$ Aug., 15 Sept., 26 Oct., 23 Nov. and 29 Dec.). When the traps were not being used, they were covered with petri plates. Specimens were preserved in $70 \%$ ethanol.

Voucher specimens are deposited in the collections of JCC, the Laboratory of Environmental Biology of the University of Texas and in the Florida State Collection of Arthropods, Gainesville.

\section{RESULTS AND DisCUSSION}

Trachyrhinus marmoratus (Family Gagrellidae) is an uncommon species distributed throughout North America from Montana and North Dakota south and west to Baja California Norte, Durango and Zacatecas (Cokendolpher, 1981). Although this species is widely distributed, we know little of its biology. Cokendolpher (1981) listed natural history data for other members of the genus, but was unable to present any for this species.

We found that populations of both females and males were surprisingly high as early as January (Fig. 1). Populations of adults then peaked in late May (dry season in the Chihuahuan Desert), after which they declined. We previously reported that this species is most active in western New Mexico in late fall or early winter (Cokendolpher et al., 1993). Apparently adults mated in or prior to May, females laid eggs and the adults either perished during May or retreated from surface habitats. Since few adult harvestmen were collected after August, the latter seems more likely. 


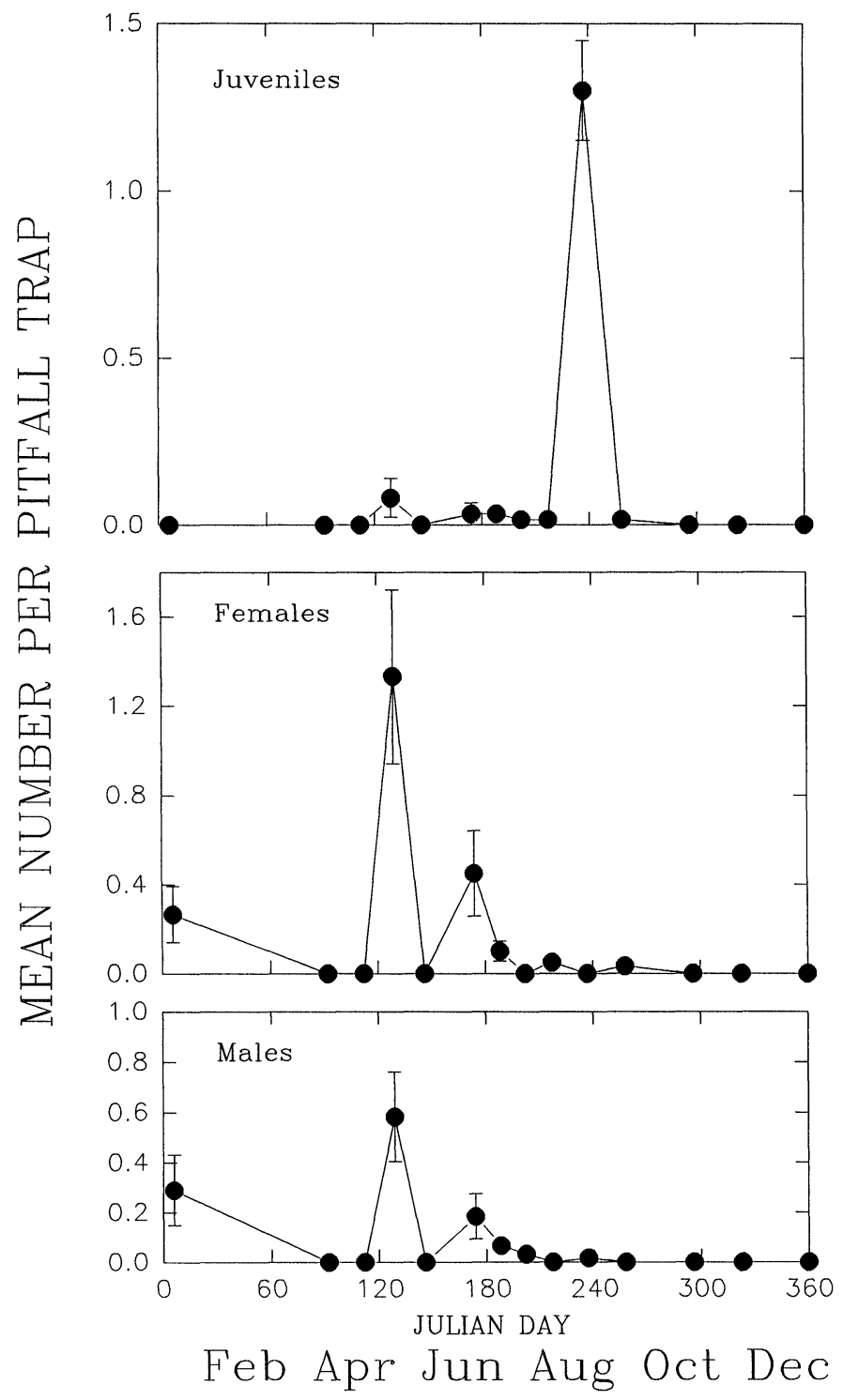

Fig. 1. Seasonal changes in populations of juveniles, females and males of the harvestman, Trachyrhinus marmoratus, in western Texas during 1991. Julian dates are indicated. The error bars are standard errors of the mean. 
Estivation has never been examined in opilions, but may account for the absence of activity from September to January, although this seems unlikely as desert rains occur during this period (July September). Egg laying has previously been reported as occurring either in the spring or late fall (Cokendolpher et al., 1993). Apparently there is either no specific time of the year when egg laying occurs or egg laying occurs in the cooler, moister seasons. The juvenile population was at or near zero until late August when we recorded a large increase, 112 days after we recorded a peak in the adult population (Fig. 1). It is probable that one or more early instars were developing below the surface of the ground before we recorded the peak in the juvenile population.

Harvestmen were collected in highest numbers on the rocky ridge. This is especially true of the adults: we only collected two adults (one female, one male) in the surrounding area, 59 specimens collected in the surrounding areas were juveniles. There appear to be two hypotheses to explain these observations: 1) the juveniles were born on the rocky ridge and dispersed into the surrounding areas to avoid competition or 2) the eggs were laid in the open area, and juveniles hatched and lived under rocks and in earth cracks. Actually neither hypothesis has much support. Competition would not be expected to be important as the adult populations were low when the juvenile population was high (Fig. 1), and the total juvenile population was less than the earlier total adult population (Fig. 1). There were abundant variety and numbers of arthropods (in the pitfall traps) in all of the transects, which presumably would have offered a food supply to the juveniles in any of the areas. The second hypothesis is not supported as we did not note any major dispersion of the adult population into the surrounding area prior to the emergence of the juvenile population (Fig. 2) (only two adults captured).

Harvestmen in North America are parasitized by a variety of mites of the genus Leptus Latreille (Erythraeidae). Only the larval forms are parasitic (protelean parasites) while the nymphs and adults are predaceous on small insects. Only two species that are named are parasitic on harvestmen (from the eastern United States, see Fain et al., 1987). Cokendolpher (submitted) reported numerous other species of mites from harvestmen in the central and southwestern U.S.A., as well as records of parasitic mites from Trachyrhinus rectipalpus Cokendolpher and T. marmoratus in 


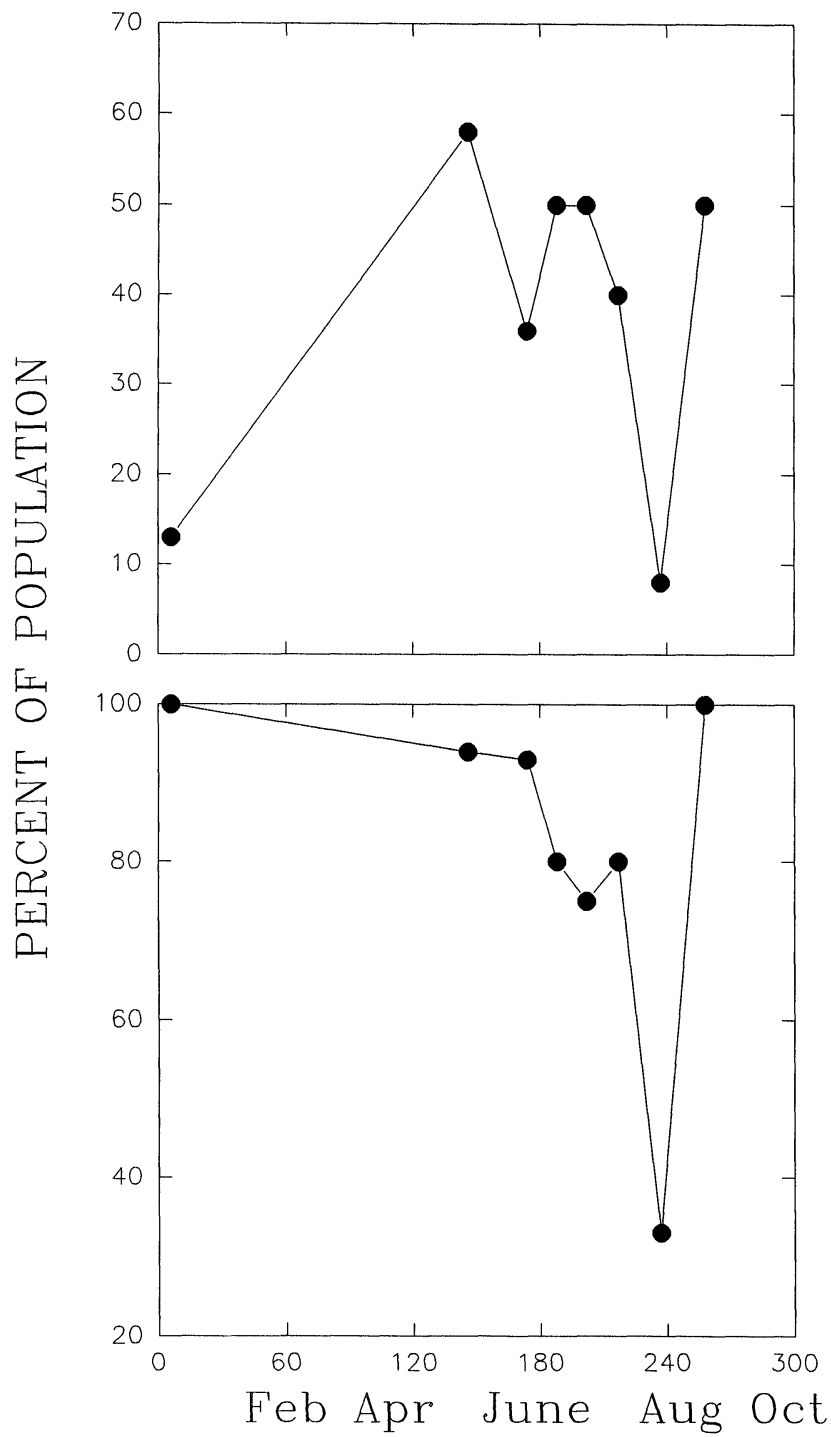

Fig. 2. Percent of the population of Trachyrhinus marmoratus infected with Leptus sp. (top) and the percent of the population found on the rocky ridge (bottom). The percent of the population found in rocky areas on day 240 consists almost entirely of juveniles; before day 240 it consisted almost exclusively of adults. 
western Texas. The Leptus sp. from our study area is undescribed (Cokendolpher, submitted).

There was considerable variability in the percent parasitism by the ectoparasitic mite Leptus sp. (Fig. 2) and much of the variability is probably due to random error. Parasitism appears to be low early in the year, peak in early summer, and possibly drop later in the year (Fig. 2). Most was parasitism of adults; only four juvenile harvestmen (collected on 23 June, 25 Aug.) were parasitized. The population of parasitic mites was negatively correlated with the occurrence of harvestmen in the surrounding area, which suggests that mites do not frequently occur in the surrounding area (or the mites do not attack juveniles or were not in the proper life stage to be parasites at that time). If parasitism occurs predominantly in the rocky area, the post-parasitic mites would drop off the harvestmen and feed on small insects among the rocks. Oviposition of the mites would likewise take place among or under the rocks where the young would wait for harvestmen hosts.

Harvestmen are not well known in deserts (Crawford, 1981; Cokendolpher, 1990; Hunt, 1991), although species have been reported from essentially all deserts (Cokendolpher et al., 1993). We found that Trachyrhinus marmoratus was surprisingly abundant at our study area. We captured large numbers in our pitfalls, and saw large numbers of them moving over the rocks and boulders at night, during the dates that large numbers were captured. There were no other abundant species in our study area during 1991. The only other species of opilion from the study site was represented by a single female of an undescribed species of Eurybunus Banks (Gagrellidae?).

\section{SUMMARY}

Harvestmen populations in arid habitats have rarely been found. We discuss the changes in a population of Trachyrhinus marmoratus Banks (Gagrellidae), a species of harvestman which is locally common in specific areas of the northern Chihuahuan Desert. Populations of adults increased throughout the early spring and peaked in midsummer. This peak was followed by a peak in the juvenile population. The harvestmen were usually found on a rocky ridge, but later in the summer our data suggest they dispersed into the surrounding area. Parasitism by the ectoparasitic mite Leptus sp. 
(Erythraeidae) was high early in the year. We only collected one other harvestman species, an undescribed species of Eurybunus Banks (Gagrellidae?).

\section{ACKNOWLEDGMENTS}

Our research was supported by the University Research Institute of the University of Texas, El Paso. An anonymous reviewer made several important improvements in the manuscript.

\section{LiTERATURE CitED}

COKENDOLPHER, J. C.

1981. Revision of the genus Trachyrhinus Weed (Opiliones, Phalangioidea). J. Arachnol. 9: 1-18.

1990. Harvestmen of Egypt (Arachnida: Opiliones). Serket 2: 9-13.

submitted. Pathogens and parasites of Opiliones (Arthropoda: Arachnida). J. Arachnol.

CoKendolpher, J. C., W. P. MAcKay \& M. H. Muma

1993. Seasonal population phenology and habitat preferences of montane harvestmen (Arachnida: Opiliones) from southwestern New Mexico. Southwest. Natur. In Press.

CRAWFord, C. S.

1981. Biology of desert invertebrates. Springer-Verlag. Berlin $314 \mathrm{pp.}$

FAIN, A., S. L. GUMMER \& J. O. WhitAKER

1987. Two new species of Leptus Latreille (Acari, Erythraeidae) from the U. S. A. Intern. J. Arachnol. 13: 135-140.

HuNT, G.

1991. Harvestmen (Opiliones) in arid and semi-arid Australia. Austral. Arachnol. no. 41: 3-5.

Muma, M. H.

1980a. Solpugid (Arachnida) populations in a creosotebush vs. a mixed plant association. Southwest. Natur. 25: 129-136.

$1980 \mathrm{~b}$. Comparison of ground-surface spider populations in pinyon-juniper and arid-grassland associations in southwestern New Mexico. Fla. Entomol. 63: $211-222$.

Polis, G. (ed.).

1990. The biology of scorpions. Stanford Univ. Press, Stanford CA. 587 pp. 

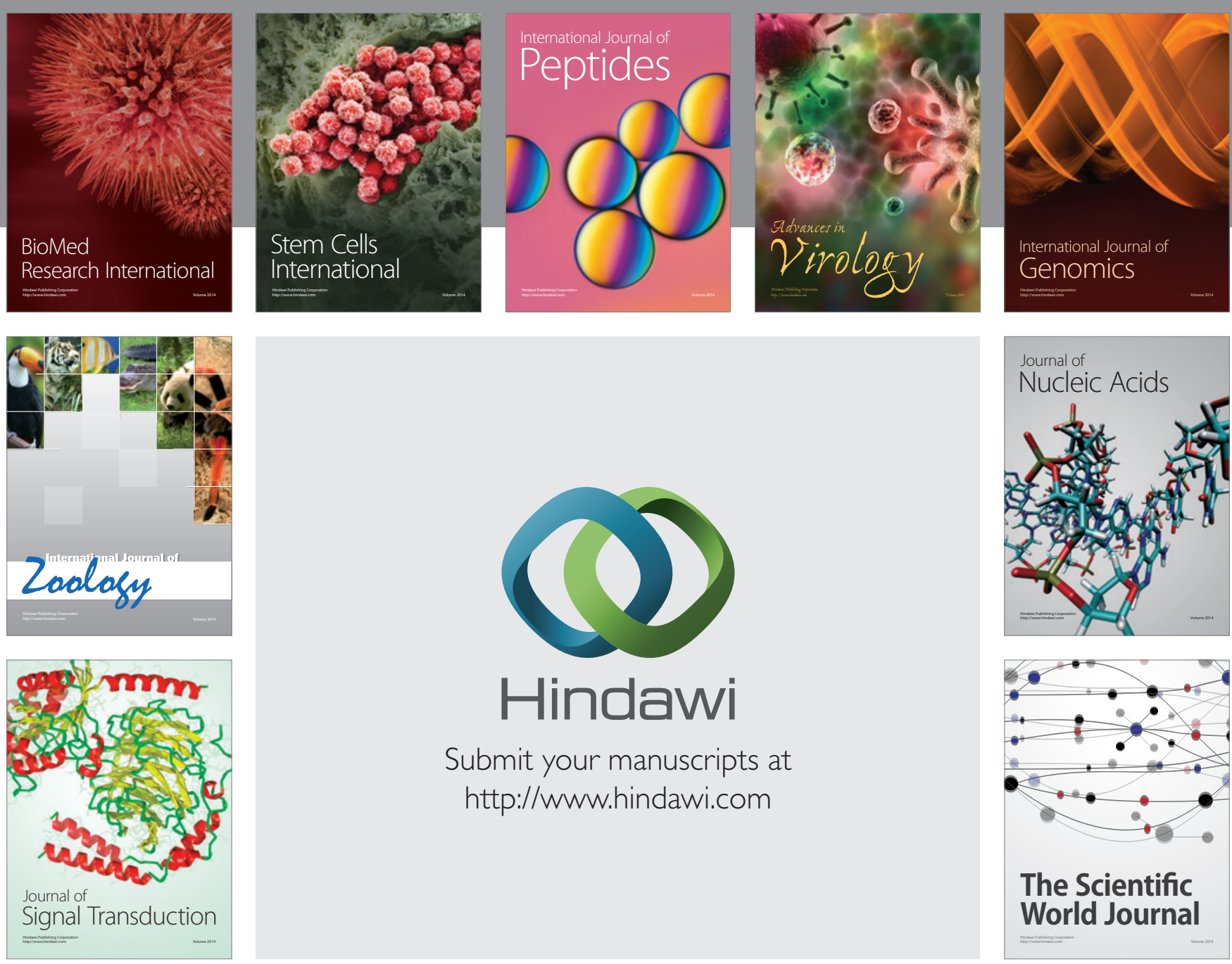

Submit your manuscripts at

http://www.hindawi.com
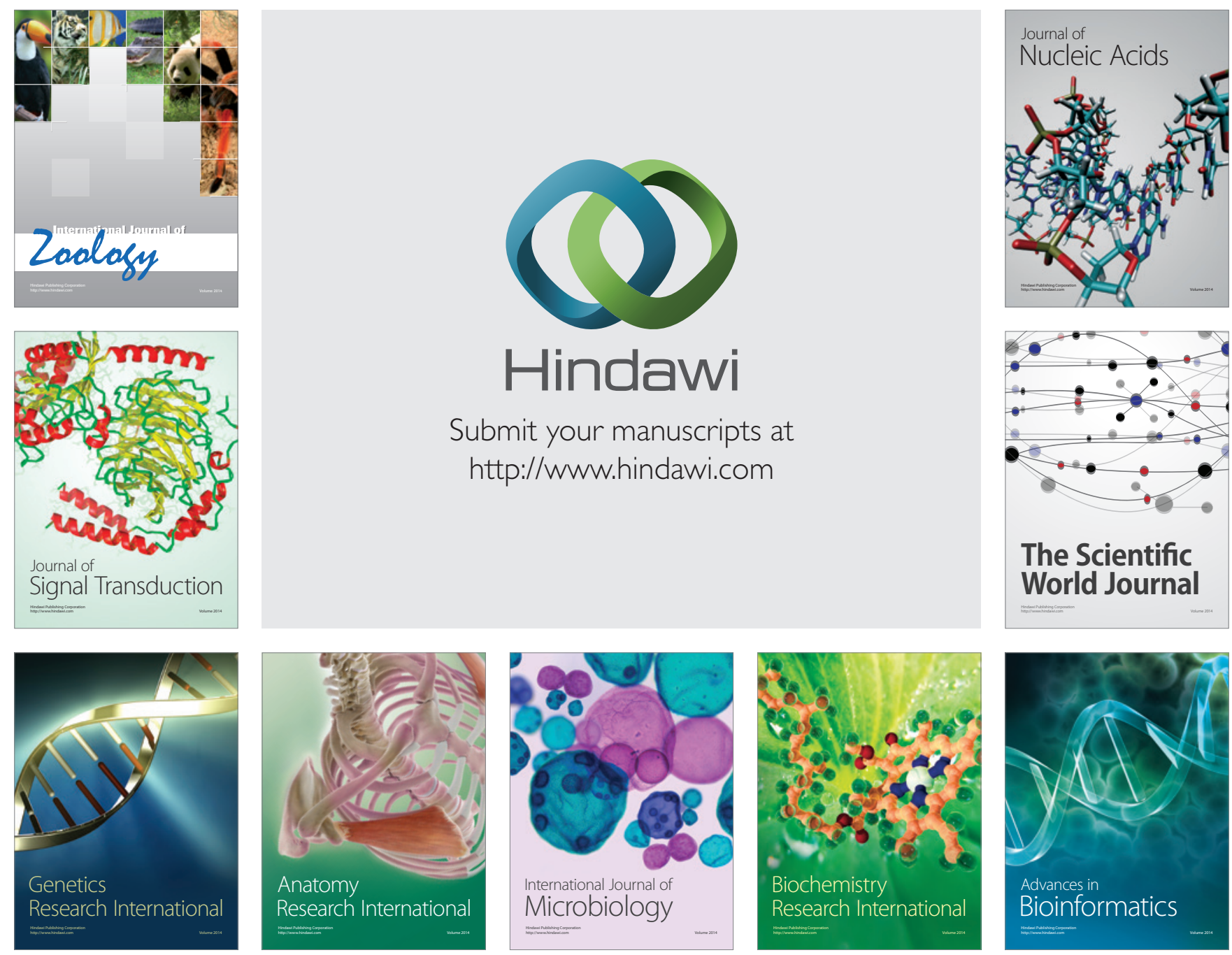

The Scientific World Journal
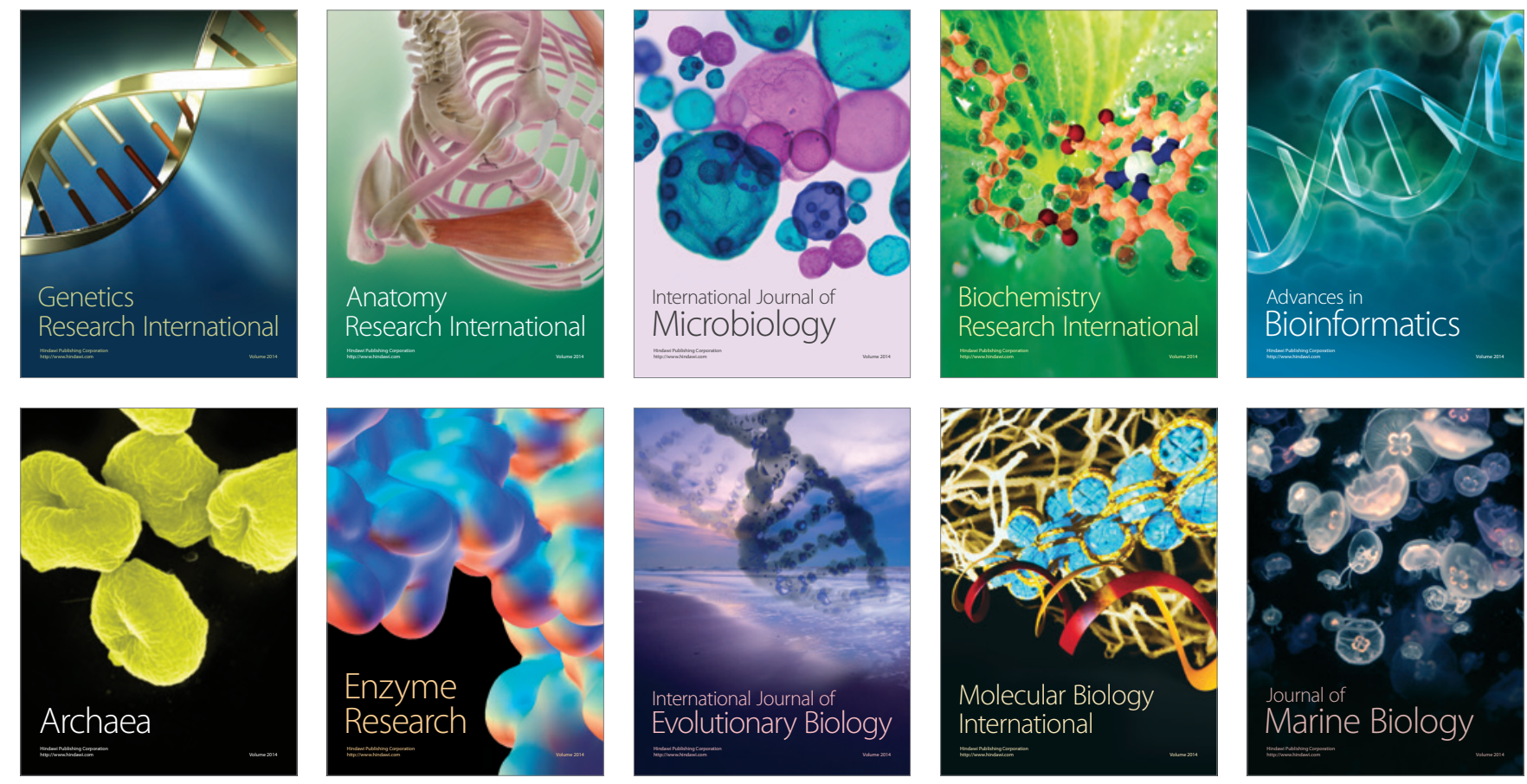